\title{
Development Policy Review

Promoting resilient livelihoods through Adaptive Social Protection: lessons from 124 programmes in South Asia

\begin{tabular}{|r|l|}
\hline Journal: & Development Policy Review \\
\hline Manuscript ID: & DPR-Jul-11-0665.R1 \\
\hline Manuscript Type: & Original Article \\
\hline Keywords: & $\begin{array}{l}\text { Adaptive social protection, Disaster risk reduction, Climate change } \\
\text { adaptation, Vulnerability reduction, South Asia }\end{array}$ \\
\hline \multicolumn{2}{|l}{} \\
\hline
\end{tabular}




\title{
Promoting resilient livelihoods through Adaptive Social Protection: lessons from 124 programmes in South Asia
}

\begin{abstract}
Adaptive Social Protection refers to efforts to integrate social protection (SP), disaster risk reduction (DRR) and climate change adaptation (CCA). The need to integrate these three domains is now increasingly recognized by practitioners and academics. Relying on 124 agricultural programmes implemented in 5 countries in Asia, this paper considers how these elements are being brought together, and explores the potential gains of these linkages. The analysis shows that full integration of SP, DRR and CCA interventions is still relatively limited but that when it occurs, integration helps to shift the time horizon beyond short-term interventions aimed at supporting peoples' coping strategies and/or graduation objectives, toward longer-term interventions that can assist in promoting transformation towards climate and disaster resilient livelihood options.
\end{abstract}

\section{Introduction}

Global crises, such as the Food-Fuel-Financial crisis that affected the entire world in 2008-09, but also more localised shocks (floods, droughts, hurricanes) are part of the wider pool of climate change-driven events and natural disasters that are increasingly impacting local populations and deepening the risks faced by many poor and vulnerable communities, particularly those involved in agriculture and other ecosystem-dependent livelihoods, in developing countries (Adger, 2007; Fiott et al., 2010; IPCC, 2007).

Social protection, disaster risk reduction and more recently climate change adaptation, are three communities of practices that were developed with the main objective of reducing the impacts of those shocks and hazards on individuals and communities by anticipating risks and uncertainties. All three communities of practices are therefore linked by a fundamental concern with reducing vulnerability and building resilience - be it to poverty, disasters or long-term changes in average climate conditions and their distribution over time and space. 
To date, however, little cross-fertilisation has been occurring between these three communities (World Bank 2011). The three streams seem to work essentially in silos, ignoring or being unaware of their commonalities and overlapping agendas, or being unable to overcome institutional constraints or poor communication that prevent them from working together. This lack of collaboration matters, because there are increasing concerns that these three communities of practices will not be successful to reduce vulnerability in the long run if they continue to be applied in isolation from one another (cf. Bayer, 2008; Bockel et al., 2009; Heltberg et al., 2009; Shepherd, 2008).

Yet, the integration of social protection, disaster risk reduction, and climate change adaptation holds intuitive appeal. Many already recognize that it would help creating and fostering synergy between vulnerability-reduction interventions that are often planned in and implemented by different ministries. In a context of scarce human and financial resources (as it is often the case in developing countries) a more integrated or coordinated approach between these three communities would also help reduce the risk of duplication or possibly conflicting interventions.

In fact a review of recent literature from a variety of different sources confirms that a growing consensus is emerging around the need to integrate social protection (SP), climate change adaptation (CCA), and disaster risk reduction (DRR). The Stern Review (Stern 2006), for instance, called for strong action on climate change and for integrating this into development thinking more broadly, not least because of the probable increases in the frequency and intensity of natural disasters resulting from climate change. The 2007/8 UN Human Development Report (HDR) made a similar point, recommending that CCA should be at the heart of the "post-2012 Kyoto framework and international partnerships for poverty reduction" (2008: 30). The same HDR also argued that it would be critical to "expand multilateral provisions for responding to climaterelated humanitarian emergencies and supporting post-disaster recovery" (ibid). Stern later went on to single out social protection as a key component of adaptation and 
called for integrating "climate risk, and the additional resources required to tackle it, into planning and budgeting for and delivering these development goals" (2009: 37).

In parallel with the release of the 2007/08 HDR, the World Bank also published a review of the role of major cash transfers in its various post-natural disaster interventions implemented in Turkey, Sri Lanka, the Maldives and Pakistan (Heltberg, 2007). It followed this up with a report on the contributions social policy interventions - such as health, education, community-driven development and in particular social protection interventions - can make to adaptation, and to reducing vulnerability to extreme climate impacts at the household level (Heltberg et al., 2009). Contributing to the critical mass building up, the Swedish Government's Commission for Climate Change and Development commissioned a briefing paper on SP and CCA (Davies et al., 2008a).

More recently, Mearns and Norton (2010) put these considerations into a broader climate change context by advocating the need to bring the social dimensions of climate change centre-stage. They argue in favour of addressing the issues of equity and social justice which underpin vulnerability, be it to climate change impacts or poverty more broadly. Building on the argument that reducing vulnerability to disasters must be a central part of adaptation, Heltberg et al. (2009) suggest that social policies have a key role to play in this respect. To the central role of social protection in adaptation, they add another critical consideration, namely that of adapting at many different levels, such that household adaptations are supported by international actions that endorse a social justice agenda and propose to share the burdens of climate change globally. The issue of scale is at the heart of robust and enduring responses to addressing the underlying vulnerabilities which leave hundreds of millions of poor people at risk to climate change impacts and chronic poverty (cf. Mearns and Norton, 2010).

Other international development organisations, such as the World Food Programme (WFP), the United Nations Food and Agriculture Organisation (FAO) and the United 
Nations Children's Fund (UNICEF), have begun to examine linkages between SP and CCA in a more detailed national context. For example, UNICEF recently released a scoping study of linkages and synergies between CCA and SP in Cambodia (Stirbu, 2010).

Despite these recent momentum-building efforts, relatively little is known to date about the technical and institutional challenges associated with the integration of these disciplines in real-life vulnerability-reducing programmes and the actual impacts (positive and negative) that this integration has on the lives and livelihoods of the households enrolled in these composite programmes. To contribute to filling this gap, this paper presents the findings of a regional analysis implemented on 124 programmes and projects designed to enhance the resilience of agriculture-based livelihoods of households in five countries in South Asia - Afghanistan, Bangladesh, India, Nepal and Pakistan. The goal of the analysis was to provide a detailed assessment of the ways in which SP, CCA, and DRR approaches are brought together. To frame the research, the study articulated two main questions:

1. To what extent are social protection, disaster risk reduction and climate change adaptation approaches being integrated in programmes and projects?

2. Where integration is occurring, in what ways are such programmes and projects intended to promote resilience amongst the poorest and most vulnerable people?

The focus of the research was at the national level, looking at both policies and programmes, and considering government, NGOs (local and international), and donor interventions.

Using these findings, the paper aims to further our understanding of how SP, DRR and CAA can be integrated on the ground, and to discuss what lessons can be learned in terms of developing better approaches to vulnerability reduction in the future. By so doing the paper advocates for what it calls adaptive social protection. The concept of adaptive social protection (ASP) has been developed in an effort to support the 
combination of SP, CCA, and DRR in policy and practice (Davies et al. 2008b; Davies et al. 2009). By bringing together the objectives of three streams of work, it aims to provide a framework that helps social protection interventions become more resilient to risks from disaster hazards and climate change, and at the same time help understand how social protection, through its vulnerability reduction interventions, can play a critical role in reducing/buffering the negative impact of climate change and disaster. As such the concept of ASP is a direct attempt to respond to the silos approach that characterises SP, CCA, and DRR and has prevented policy-makers, institutions, and practitioners in those three domains from working together.

The rest of the paper is organised as follows. After a brief introduction on SP, section 2 outlines some of the current discussions on the implementation of social protection in relation to DDR and CCA. Building on these discussions the concept of ASP is also presented in section 2. The methodology used for the analysis is then described in section 3, while section 4 presents the main findings of the analysis. Section 5 discusses these in greater detail, along with their policy implications. Section 6 concludes.

\section{Linking SP, DRR and CCA: current understanding}

\subsection{Social protection: a growing development agenda}

The concept of SP has evolved in recent years from a relatively narrow focus on safety nets in the 1980s and 1990s to present-day definitions that include short-term interventions to reduce the impact of shocks, but also, increasingly, consider longerterm mechanisms designed to combat chronic poverty (Devereux and Sabates-Wheeler 2004; Barrientos and Hulme, 2008). In this context, it is now widely recognized that SP provides a critical entry point for addressing the rising poverty and vulnerability that characterise the current situations in developing countries (Cook et al. 2003; Barrientos et al. 2005; Ellis et al., 2008; Devereux and White, 2010; Dercon 2011) and several international development agencies have recently put SP at the centre of their strategies for alleviating poverty and managing vulnerability. The World Bank is 
currently developing its 2012-2022 Social Protection and Labour Strategy (World Bank 2011) and the latest European Development Report focuses on "Social Protection for Inclusive Development" (ERD 2010).

Social protection measures include a wide range of different interventions and instruments. Core SP interventions usually involve the direct transfer of cash or food to those experiencing transitory livelihood hardship or longer-term, more chronic forms of poverty (e.g. Devereux et al., 2005). These transfer can be conditional, whereby the transfer is contingent on, for example, member(s) of the household attending school (children) or carrying out public works (adult), or unconditional, meaning the recipient does not need to do anything to receive the transfer (Soares et al., 2008; Brown et al., 2009). Complementary SP interventions include microcredit services, and social development, skills training and market enterprise programmes. Overall, those various types of interventions are aimed at providing people with the resources necessary to improve their living standards to a point at which they are no longer dependent upon external sources of assistance, a process sometimes referred to as 'graduation' (Matin et al., 2008; Hashemi and Umaira, 2011).

Devereux and Sabates-Wheeler (2004), in an attempt to explore social protection policies in practice, proposed to categorize SP through a Protection-PreventionPromotion-Transformation (3P-T) framework. Building on Guhan's initial work (1994), the main underlying idea of the 3P-T framework is the recognition that SP goes beyond the conventional focus on safety net interventions that had characterized social protection policies in the earlier days, and includes interventions and instruments also aimed at promotion and transformation of people's livelihoods. Although no precise definition of these 3P and T categories is proposed in the literature, they are usually understood as follows. Protection measures include social policies and instruments aiming at protecting marginalized individuals or groups such as children, orphans, elderly, or disabled people through the establishment of social welfare programmes - 
e.g. pension schemes, protection programmes for child or other at-need groups. In the context of DRR, protective measures usually refer to instruments associated with shorter-term interventions such as distribution of food, or cash, aimed at supporting peoples' existing coping strategies in the immediate aftermath of a disaster. Preventive measures are defined as social or disaster-linked policies and other safety net interventions that directly seek to reduce vulnerability of individual or groups to specific shocks and hazards through for instance unemployment schemes, insurance, or food and/or cash transfers. Promotive measures include policies and interventions aimed at enhancing income, capabilities and resilience through activities such as micro-credit programmes, livelihood diversification programmes, or cash or asset transfers (e.g. starter packs). Finally, transformative measures include policies and interventions that seek to address concerns of social justice and exclusion through, e.g., promotion of minority rights or positive discrimination policies to redress discrimination and abuse.

\section{These categories may overlap in that some measures do for instance simultaneously "promote" incomes as well as "prevent" deprivation. Public works projects are examples of these situations as they aim both at transferring short-term food or cash (prevention) and building useful long-term infrastructure (promotion). The 3P-T, however, is relevant for our analysis, not the least because it encompasses the newly proposed World Bank social protection framework (which relies on the 3Ps dimensions: Prevention, Protection, and Promotion). The inclusion of the additional ' $\mathrm{T}$ ', the transformative dimension, is also extremely useful since it expands the analysis beyond this now well established 3P framework and helps focusing attention on the relatively neglected area of social risk and institutional vulnerability. As such the transformative dimension builds a case for a stronger role for social protection in terms of empowering the poor and} transforming the conditions in which they struggle to construct viable livelihoods. We argue that altogether the 3Ps and the T provide a comprehensive and rigorous framework, which will allow us to cover and analyze the various programmes and projects included in this review. 


\subsection{Social protection and disaster risk reduction}

According to Heltberg (2009), SP has formed an important and well-performing part of the World Bank's disaster response in several major recent climate-related disasters in South Asia. In these circumstances, support is often provided directly as cash to affected households, although workfare (cash-for-work) is another commonly-utilised instrument which is well-suited to the short-term relief phase (Creti and Jaspars, 2006) ${ }^{1}$. Experience suggests that it is important to have such programmes in place before the onset of natural disasters -as demonstrated in the case of the 2008 Wenchuan earthquake in China (Kabeer et al. 2010)-, with flexible targeting, financing and implementation arrangements for scaling up as appropriate (Alderman and Haque, 2006), and prevention and risk management measures already integrated in (Bockel et al., 2009).

Other social protection instruments that are also used in disasters include conditional cash transfers, near-cash instruments such as vouchers and fee waivers, social funds, and specific services such as child protection, orphanages, and rehabilitation for persons with disabilities. In Bangladesh, recent experiences of asset restocking following disasters (Marks, 2007; Devereux and Coll-Black, 2007; Tanner et al., 2007) demonstrate that such approaches can contribute to reducing vulnerability to climate shocks by providing liquidity and alternative sources of income during times of household stress (Davies et al., 2009).

\section{A particular type of risks that needs attention is idiosyncratic and covariate risks associated to market. Due to their growing dependence on markets for inputs (e.g. fertilizers, gasoil) and outputs (commercialized farming products), rural farmers are increasingly exposed to market shocks. Those can be induced by climate or weather- related disasters such as drought, or by macro-economic (national or global) crisis. To address these, efforts have so far focus essentially on ex-post relief interventions or price stabilization mechanisms. A growing numbers of projects are exploring}

\footnotetext{
${ }^{1}$ Cash for work, however, can also be used with long-term objectives.
} 
alternatives to these types of operations, pointing out in particular the potential role of ex-ante approaches such as index based weather insurance, to reduce the vulnerability of rural farming households to these market-based risks (Belete 2007; Skees, 2008).

\subsection{Social Protection and Climate Change}

Much less has been done to link SP and CCA, and bringing the SP and CCA discourses together is now recognised as a major challenge for the next few years (Shepherd, 2008; Béné 2011). Heltberg et al. (2009) argue that past social responses to ongoing climate volatility have failed to offer effective protection to the poor, and suggest that promoting approaches such as social funds, social safety nets for natural disasters, livelihoods, microfinance and index insurance would help address this gap. Coverage of programmes and instruments helping poor and vulnerable people manage climate risks remains low however, although an increasing number of examples of good practice are now documented in the literature (Jones et al. 2010).

Godfrey Wood (2011) reviews some of these examples, focusing in particular on how SP can help strengthen adaptive capacity of households in the specific case of cash transfers. She identifies 6 ways in which this can happen: when cash transfer helps (a) the poor meeting their basic needs (e.g. Awuor, 2009; Barrientos and Niño Zarazúa, 2010), (b) responding to climate-related shocks (e.g. Oxfam GB and Concern, 2007; Harvey, 2007), (c) reducing the pressure to engage in coping strategies which weaken long-term adaptive capacity (mal-adaptation) (e.g. ILO, 2008; Devereux et al., 2006), (d) transferring money for investment in long-term livelihood and adaptive capacity improvement (e.g. Neves et al., 2009; Soares et al., 2008), and (e) facilitating mobility and livelihood transitions (e.g. Azuara, 2009; Ardlington et al., 2007). However, beyond these specific examples, empirical evidence of the role of SP in strengthening CCA remains scarce.

\subsection{Disaster risk reduction and Climate Change Adaptation}


A number of researchers, policy makers, and practitioners have discussed and critiqued the similarities and differences between DRR and CCA (e.g. Shea, 2003; Sperling and Szekely, 2005; Thomalla et al., 2006; Kelman and Gaillard, 2008; Mitchell and van Aalst, 2008; Tearfund, 2008; UNISDR, 2008; Schipper, 2009); some advocate for increased convergence, whilst recognizing existing differences between the DRR and CCA agendas (e.g. Thomalla et al., 2006; Mitchell and van Aalst, 2008; Tearfund, 2008) while others outline the need to embed CCA within DRR, making climate one factor amongst many, which should be considered in reducing community vulnerability (e.g. Kelman and Gaillard, 2008; Kelman et al., 2009).

Whilst clearly different views exist, there seems also to be a growing consensus that DRR and CCA should be integrated into wider development planning (e.g. Lewis, 2007; O'Brien et al., 2006; Christoplos et al., 2009). Yet, despite a number of opportunities and global agreements that recognize and support the need to link the two agendas, and the increased recognition of the value of mainstreaming CCA into DRR activities, practitioners and policy makers also recognize that there is a lack of practical, actionable recommendations on how to create an environment where attempts to mainstream CCA into DRR can flourish.

\subsection{Adaptive Social Protection}

The concept of Adaptive Social Protection (ASP) built on those various considerations. It aims at bringing together the agendas of social protection, disaster risk reduction, and climate change adaptation together (Fig.1) both conceptually and in policy and practice (Davies et al. 2009). The underlying assumption is that combining components of these 3 domains can improve the efficiency of interventions and increase impacts on the poor's unsafe living conditions, counter the underlying causes of vulnerability, and promote people's ability to adapt to a changing climate. Taking vulnerability as the starting point provides the core conceptual link between the SP, CCA and DRR. But ASP adopts a particular approach to vulnerability, where vulnerability is viewed not simply as 
a function of risks and shocks, but also as a result of as a pre-existing socio-institutional context ${ }^{2}$, In that sense, ASP goes beyond shock or disaster-related vulnerability and attempts to embrace other more insidious root causes of vulnerability.

[insert Fig.1 here]

In addition to the fundamental concern with reducing vulnerability, ASP is characterised by considerations of temporal scale (from the short to the longer term - see Jones et al., 2010) and geographic scale (from the local to the global level - see Heltberg et al 2009). Previous works have set out the conceptual foundations for bringing the three domains together (cf. Davies et al. 2008a; Davies et al. 2008b; Cipryk 2009).

In a broad sense, ASP derives from the Sustainable Livelihoods Framework which describes how people utilise different forms of capital, such as natural or financial resources, to construct a living (Scoones 1998; Marsh 2002). But it also recognizes that the everyday risks that people face in their life do not just result in variability in living standards, and that a lack of means to cope with risk and vulnerability is in itself a cause of persistent poverty and poverty traps (Chambers 1989; Sen, 2003; Dercon 2005; Wisner, 2009). At the same time, there are potentially numerous different pathways out of poverty and vulnerability, and approaches to interventions to address these problems will vary in their suitability, depending on the national and sub-national context encountered (Brooks et al. 2009). These pathways do not just concern the transfer of material goods to poor and vulnerable people, but also the development of rights-based approaches as a means of empowering people to exercise their 'voice', and so acquire immediate benefits, but also influence processes of change and social transformation (Conway et al., 2002; Devereux and Wheeler, 2004).

\footnotetext{
${ }^{2}$ Indeed, as many pointed out (e.g. Cook and Kabeer 2010), not all forms of vulnerability can be reduced to episodic shocks or assessed in terms of fluctuations in income or consumption flows. Social relationships or institutions can give rise to forms of inequality, economic exploitation, social exclusion and political marginalisation (Cleaver 2005). These are endemic forms of vulnerability not easily accommodated within the language of risk as they reflect more endemic/structural processes.
} 
Drawing on these, ASP is premised on the potential synergies to be gained in moving away from the single-stranded approaches used so far, and promoting instead strong integration of SP, DRR and CCA policies and practices. This body of research has already outlined some of the benefits but also challenges of integrating SP with DRR and CCA, both in response to short-term climate disasters, as well as long-term risks posed by climate change. Davies et al (2009) for instance discuss in detail the benefits and challenges that specific types of SP instruments can have in promoting CCA and DRR. Table 1 synthesises some of the main points presented in this section. It also indicates the shift that takes place in timeframe when integration occurs and transfers the focus from short-term protective to longer-term promotive and transformative interventions.

[insert Table 1 here]

\section{Data collection and methodology}

A desk-based analysis of 124 programmes and projects was carried out for five countries in South Asia: Afghanistan (12 programmes/projects), Bangladesh (37), India (39), Nepal (16) and Pakistan (16), from an initial pool of 300+ documents retrieved through electronic sources (Arnall et al. 2010) ${ }^{3}$. A wide range of programmes and projects were selected for the study, from major Government-run schemes, such as the National Calamity Contingency Fund in India (MHA 2007), to smaller-scale NGO initiatives, such as Practical Action's Mainstreaming Livelihood-Centred Approaches to Disaster Management project in Bangladesh (Practical Action 2009). The commonality among all those programmes and projects was their focus on rural-based livelihoods.

A broad selection of documentation was reviewed, including peer-reviewed papers, project and workshop reports, as well as grey literature documents. In addition to this

\footnotetext{
${ }^{3}$ The projects reviewed were in different stages of progress, although most were ongoing at the time of the research. A vast majority of reports available were project descriptions which contained very little detailed programme evaluation. These were discarded and only 124 were kept for the analysis.
} 
desk-based process, 46 phone-based or face-to-face interviews were conducted with 9 regional and 37 national-level policymakers and practitioners from national and international NGOs in order to triangulate the information extracted from the literature review.

The 124 programmes and projects were categorized according to whether they had adopted an SP, DRR or CCA approach to building livelihood resilience, or a mixture of these. Thus, a project was considered to have an SP approach if its primary objective was to reduce vulnerability of individuals or groups from livelihood risk and shocks (including enhancing the social status and rights of the marginalised groups), and was using SP instruments to achieve its objectives. DRR approaches were identified by their specific focus on natural disasters, while CCA approaches were defined by their aim to assist people to adapt to climate change and variability. This initial categorization was based on the stated aims in project documents, input from the interviews, and official mandates of the implementing agencies (e.g. Ministry of Social Welfare is responsible primarily for social protection). It was recognized that individual projects were not confined to one single approach, and could draw on a variety of activities and instruments to achieve their goals. The categories used were: SP, DRR, CCA, SP-DRR, SPCCA, DRR-CCA, and SP-DRR-CCA. In assigning programmes to the integrated categories (last four) we accounted for programmes that had stated objectives and/or instruments that spanned in more than one field.

Following this initial categorization, we then used the Protection-PreventionPromotion-Transformation (3Ps-T) framework as an analytical tool to provide insights into the integration process and its potential influence on the nature of the interventions included in the programmes. This exercise was done by examining the stated objectives of the projects and determining whether the projects were aimed to protect, promote or transform peoples' livelihoods, or prevent harm from occurring to them. It should be noted that the analysis was not aimed at assessing the actual impacts 
of these programmes -analyzing objectives is not the same as assessing whether these objectives are effectively achieved on the ground.

Although different combinations of integration among SP, CCA and DRR were possible the focus of the analysis was on programmes involving some element of SP. We were in particular interested in analyzing the effect of including DRR and/or CCA objectives on SP programmes.

Two caveats should be mentioned here. First, the pool of the 124 programmes that were included in this research did not result from a random sampling procedure but from a selection process based on the availability and quality of programme documents and advice from interviewees who were contacted because of their experience and knowledge of these fields. Unavoidably therefore, our analysis reflects - at least to some extent - the composition of the pool of selected programmes. Second, the 3P-T typology used for the second part of the analysis may introduce some degrees of subjectivity. What determines the 'promotive', 'preventive', protective' or 'transformative' nature of an intervention is based on criteria developed by researchers at IDS (summarized in Davies et al. (2009) and subsequent works). As clear indicators for these criteria are still evolving, the decision of whether a programme contributes to the protection, promotion, or transformation of people's livelihoods can certainly be debated. In fact a large number of the programmes and projects included in the analysis were considered to embrace not one, but two, or sometimes three of the Ps and T dimensions (see results below).

\section{Findings}

\subsection{Degree of integration of SP, DRR and CCA}

Of the 124 projects and programmes examined ${ }^{4}, 97$ (78\%) contain a significant SP element, 72 (58\%) a DRR component, and 43 (35\%) a CCA component. Fifty eight

\footnotetext{
${ }^{4}$ The full list of these 124 programmes is provided in Appendix 1.
} 
percent of the projects and programmes integrate at least two disciplines and $16 \%$ integrate all three, while the remaining $42 \%$ involve just one discipline.

Table 2 shows the number of projects and programmes that integrate the various vulnerability-reducing components from the perspective of individual disciplines. SP projects tend to integrate with the other two disciplines the least, with almost half of all SP projects having no integration at all. In contrast, DRR or CCA projects are almost always integrated with at least one other discipline. Of these, projects with CCA elements appear to combine all three disciplines the most, with $41 \%$ of such projects also containing significant SP and DRR components.

[Insert Table 2 here]

SP and DRR are the most common combination of disciplines found in the projects and programme examined in this study, with a total of 28 using an SP approach specifically to build disaster resilience. Approximately three quarters of the projects reviewed in this SP-DDR category, however, adopted a narrow conceptualisation of vulnerability, meaning that they only responded to the consequences of a disaster or the immediate, most obvious causes of vulnerability, such as the physical location to a disaster. In these projects there was often an emphasis on protection and returning to 'normalcy,' rather than focussing on the conditions that caused risk and vulnerability in the first place. Some would argue that in many cases, these 'normal' conditions are directly or indirectly contributing to risk and vulnerability (O'Brien et al, 2008: 16).

The remaining SP-DRR projects reflect a more holistic understanding of the root causes of vulnerability. In particular, several agencies undertook a number of vulnerability analyses and mapping exercises as part of projects aimed at prevention through building disaster resilience or increasing food security. This is the case for instance of the Food Security Information and Early Warning System implemented by the FAO in Bangladesh 
and India, which is using both physical mapping techniques and demographic data to characterise the most vulnerable populations and better understand the underlying causes of food insecurity (FAO 2011).

Table 3 details the degree of integration of SP, DRR and CCA domains on a regional and country-by-country basis. Bangladesh and India appear to have the highest percentage of projects combining all three disciplines (22\% and $21 \%$ respectively), whereas

Afghanistan, Nepal and Pakistan have almost none. This suggests that Bangladesh and India have made the most progress in integrating SP, CCA and DRR element into their vulnerability-reducing agricultural projects, possibly because DRR and CCA are higherprofile issues in these countries ${ }^{5}$.

[Insert Table 3 here]

Dedicated SP projects and programmes are common in all countries reviewed. This is particularly the case in Afghanistan, which is characterised by an unusually high number of food security projects, partly resulting from the high protection needs in a country that faces enormous recovery challenges following three decades of war, civil unrest and recurring natural disasters. Similarly, a relatively high proportion of Pakistan's projects combine SP and DRR approaches compared to other countries, possibly as a result of the devastating 2005 earthquake. The 2010 flooding (the worse in a century) which has been estimated to have affected more than 20 million people- will probably contribute to reinforce this trend.

In summary, the findings presented here suggest that ASP projects (full integration of SP, DRR and CCA) is relatively limited in South Asia, although overall there has been significant progress made in combining SP with DRR in recent years. Of the three

\footnotetext{
${ }^{5}$ Bangladesh is also considered one of the most vulnerable countries to climate change, and addressing it is a priority. For illustration, it was the first country to include in its constitution a provision for redressing damage resulting from climate change.
} 
vulnerability-reducing domains reviewed, the SP component is integrating the least with the other disciplines. Where SP is being integrated, it is mainly associated with DRR, and this reflects the trends noted in the literature review in Section 2.

\subsection{Contribution of SP to resilience (through integration to DDR and/or CCA)}

Having identified the level of integration between disciplines, we then considered how integration can build resilience, using the protecting, preventing, promoting, and transformative 3P-T framework. The findings are presented in Fig.2.

[insert Fig.2 here]

In the case of SP projects with no integration, the data show that protection and promotion measures are relatively common ( $44 \%$ and $40 \%$ respectively). The potential value of protection to the wider objectives of promoting resilience to shocks and stresses is that 'SP programmes like cash grants and food aid [reduce] the need for coping strategies that lead to long-term poverty traps' (Narayan and Zaman 2008: 95). Thus, approximately half of the non-integrated SP projects and programmes combine objectives that intend to protect and promote into a single package of interventions. Where these protection and promotion measures are combined, the core SP instruments are often broadened to include complementary mechanisms, which has the effect of increasing the timescale over which the intervention is supposed to occur. The 14 food-security projects considered here range from reactive programmes that have the simple objective of alleviating famine and hunger in times of drought or during and immediately after disasters, through to comprehensive long-term programmes aimed at reducing the cause of food insecurity. The latter types of programmes commonly utilise multiple approaches, including food or cash for work, micro-credit, livelihood diversification, and seed and soil improvement schemes. An example is the Rural Community Infrastructure Works (RCIW) project in Nepal that has the objective of generating improvement in the long-term food security and livelihoods of households in 
the most food-deficit districts in the country (Anon, 2006). To achieve this, the RCIW has adopted a multiple-intervention approach that includes a food-for-work programme aimed at alleviating food insecurity in the short-term and creating productive assets in the long-term.

The final remaining set of projects includes those that attempt to combine SP with both CCA and DRR instruments (ASP approach). The analysis shows that the level of promotive measures remains relatively constant and high. In contrast, as the degree of integration of SP with DRR and CCA increases, the number of projects and programmes taking a protection approach decreases drastically, while preventive and transformative interventions increase (Fig.2). A good example of this is the Empowerment and Livelihood Improvement "Nuton Jibon" Project in Bangladesh. In that project community-driven development strategies were introduced with the objective to reduce vulnerability of the poor to risks, in particular those associated with natural hazards and climate variability, through a combination of transformative and promotive activities, namely (i) empowering the poor and strengthen local governance by developing sustainable, participatory and accountable rural community institutions, (ii) increasing employment opportunities by enhancing skills, supporting the start up or expansion of income generating activities, and strengthening access to markets and financial institutions; and (iii) supporting small-scale demand-driven community investment sub-projects that were prioritized, implemented and managed directly by the rural poor (Vakis 2006).

\section{Other examples of programmes that adopted a similar ASP approach are displayed in} Table 4. These include the Chars Livelihood Programme in Bangladesh, the Pilot Project on Climate Change Adaptation for Sustainable Rural Development in India (Gol 2006), or the Shouhardo project run by Care in Bangladesh. What all these programmes have in common is an integrated approach where the transformative component is usually embraced by placing special emphasis on reaching and empowering the poorest 
members of society and by supporting a wide variety of activities including training combined with a daily stipend, micro-enterprise development, and provision of leasehold farming to landless households, crop diversification and land transfers. Note however that whether or not these transformative objectives are achieved is not clear from the documents that were reviewed in this analysis.

[insert Table 4 here]

\title{
5. Discussion: Linking SP with CCA and DRR in practice
}

The underlying rational for this study is the recognition that, although driven by a common aim to reduce vulnerability, experts working in social protection, climate change adaption and disaster risk reduction do not necessarily find the ways to speak to each other. As admitted by Andrew Steer the World Bank Special Envoy on Climate Change:

\author{
"For the most part, these three fields have developed in their own silos: \\ adaptation in ministries of the environment, disaster risk management in \\ ministries of the interior or civil protection, and social protection in ministries of \\ social affairs. These silos have been replicated in development agencies, where \\ teams have operated in parallel systems" (World Bank 2011, p.5)
}

The consequences of this lack of effective collaboration are multiple. These include duplication of efforts, administrative inefficiencies, or even competition among various groups, which could not only hamper their respective efforts, but possibly compromise the overall effective use of resources. At a more technical level, there are also risks that non-collaboration leads to some counterproductive effects. For instance, the rapid expansion of climate change related efforts may waste time and risk reinventing older approaches if these efforts neglect learning from the experiences, methods and tools developed for disaster risk reduction. On the other hand, efforts on disaster risk 
reduction that do not take account of the impacts of climate change on the frequency and magnitude of hazards may not only fail to achieve their objectives, but may even increase vulnerability, for instance when flood defences provide a false sense of security and fail to provide lasting protection against rising flood risk triggered by long-term climate changes.

Our objective in this paper was therefore to better describe and understand how SP, DRR and CAA can be integrated on the ground, and to discuss what lessons can be learned in terms of developing better approaches to vulnerability reduction in the future. For this we used a pool of 124 programmes and interventions that were implemented in 5 countries in Asia. The analysis, however, was not intended to provide a detailed assessment of the evidence, nor to consider the impact or effectiveness of these programmes. It was instead aimed at offering an initial analysis of the ways in which SP, CCA, and DRR approaches can be brought together in practice at the design or implementation stage of programmes and projects.

The analytical framework we used to conduct our analysis was the 3P-T framework proposed initially by Devereux and Sabates-Wheeler (2004). The expected relevance of the framework relied initially on the abilities of its four dimensions to provide a comprehensive coverage of the various types of programmes and interventions currently implemented in SP, CCA and DDR. As will be discussed below, the time-frame indirectly associated to the 3Ps and the T dimensions (highlighted in Table 1) turned out to be another important element contributing to the appropriateness of the framework for this study. This is in large because the framework encompasses and links efforts at reducing vulnerability to shocks and stresses which occur across short-to-long-term timescales. Indeed SP, but also CCA and DRR are no longer just about responding to shocks through short-term reactive responses, but also about tackling structural and underlying longer-term causes of chronic poverty and vulnerability. 
The analysis of the 124 programmes shows that full integration of SP, CCA and DRR approaches into ASP is relatively limited in South Asia, although combining SP with DRR has become more common in the last ten years. Many of the SP and SP-DRR programmes that were examined in this review are concerned with protection and promotion measures. In general the combination of these measures within a single programme has the effect of expanding the time horizon over which the intervention operates, thus increasing its support for longer-term goals that are relevant in interventions such as CCA programmes. On the other hand, projects with initial CCA objectives appear to combine all three disciplines the most, with $41 \%$ of these CCA projects also containing SP and DRR measures (Table 2). Arguably this higher level of integration in CCA programme is observed because CCA is a relatively new policy framework compared to DRR in particular, and is therefore in a relatively early stage of experimentation where it is possible to draw on and include other domains' experience. CCA might also be most closely related to the other two approaches in terms of how it translates into practical interventions on the ground.

In the case of SP-DRR projects, a number of new and innovative approaches to vulnerability reduction can be observed. Of particular interest is the use of vulnerability mapping in food security and DRR projects where multiple social and natural science disciplines focussing on risks and poverty assessment are combined together. This finding suggests that there has been some movement within the DRR community towards acknowledging and integrating the underlying social dimensions of vulnerability that people face. This is in line with recent attempts to shift DRR away from reactive, post-disaster coping strategies, such as providing food aid, towards more proactive and long-term disaster preparedness and management (Heltbert, 2007; Hellmuth et al., 2011).

In contrast to SP-DRR programmes, much fewer projects integrating SP with CCA objectives seem to be developed in South Asia. More research is required here to better 
understand why this type of integration is slower to emerge and how the expected benefits of the kind listed in Table 1 could effectively play out in the longer-term.

From a more theoretical point of view it is useful to point out that the link between CCA and SP, and more broadly between adaptation and development, is still quite unclear.

This is reflected for instance by the fact that it is almost impossible to find a definition of development or adaptation which does not invoke the concept of change. In that context, some commentators have argued that 'adequate development' subsumes adaptation, because it will "automatically" reduce risk (Lavell, 2004:73). Some would also consent that there are many examples of development intervention that would foster adaptation, whether or not explicitly formulated with that objective in mind. Others, however, like Adger and his co-authors (2003), caution us against the assumption that development intervention will automatically address adaptation and climate considerations. In particular, those authors argue, it cannot be taken for granted that current and future development interventions will always be resistant to the magnitude of climate change impacts that the twenty-first century is likely to experience, or will systematically offer sufficient flexibility in the face of the considerable uncertainty surrounding the severity and distribution of those impacts. This point is particularly relevant for our discussion as it applies to social protection interventions. Also pertinent to this agenda, is the fact that assumptions around adequate development may not always encourage practitioners and experts to inquire into how much resilience is built into an intervention, or to examine its limits. Recent field-based research conducted by the African Climate Change Resilience Alliance (ACCRA) for instance highlights that many NGO-led livelihood interventions in rural areas in Africa are missing valuable opportunities to increase the adaptive capacity of vulnerable populations to future climate and development pressures (Levine et al., 2011). This highlights the need for more research into how standard development interventions - such as social protection - can better promote adaptation. Only then 


\section{can we hope to gain a clearer understanding of the extent to which such interventions} are 'adequate'.

To return to our analysis and the main findings that emerged from this review, data finally suggests that where SP, DRR, and CCA are being combined together into ASP programmes, these programmes put relatively greater emphasis on prevention and transformation interventions and less on protection measures. This result is not too surprising since protection measures are often associated with short-term interventions aimed at supporting existing peoples' coping strategies in the immediate aftermath of a disaster (Mitchell et al. 2010). In that context the reduction in protection focus is expected to reflect the inclusion of CCA objectives, which expands the time horizon considerably beyond the vulnerability-reducing intervention period. Conjointly, the increase in prevention measures in these ASP projects appears to be largely due to the use of insurance schemes. In fact, some of the most innovative projects combining SP, DRR and CCA are based around weather-indexed insurance on crop and livestock for small-scale farmers -such as the Application of Community-Based Adaptation Measures to Weather Related Disasters led by the Himalayan Climate Centre in Nepal (ACCA 2008), or the Indian Pilot Project on Climate Change Adaptation for Sustainable Rural Development implemented by the Ministry of Environment and Forests (WRI 2007). These examples suggest that micro-insurance has a potentially important role to play in integrating CCA with DRR and SP .

Alongside prevention, the transformative nature of these ASP projects also increases substantially. This increased focus on transformative interventions relies on various types of measures such as changes in land distribution and in access to leasehold farming for landless households. These projects tend also to broaden poverty and vulnerability reduction goals, and appear therefore to be promising for promoting

\footnotetext{
${ }^{6}$ Some would argue however that one of the major drawbacks of these micro-finance schemes is their failure to reach the poorest and most vulnerable individuals on the ground.
} 
climate resilient livelihoods. More evidence is required however about the real impacts that these ASP projects have on the ground.

Through the systematic review of these programmes and projects, this research also revealed a series of secondary findings, a number of which are particularly relevant to agricultural sector policy in South Asia. First, many of the promotive projects reviewed spread risk by diversifying peoples' livelihoods away from climate sensitive activities such as rainfall dependent subsistence-oriented agriculture, towards activities that are more resilient. For example, the aim of the Improving Capacity of Vulnerable Households project in Bangladesh (BCAS 2004) is to increase the capacity of communities in the Gopalganj district to adapt to the adverse effects of climate change through diversification of livelihood options.

Second, the presence of micro-insurance in the small but growing number of projects integrating CCA with DRR and SP suggests that designers and managers expect these preventive instruments to have a potentially important role to play in supporting climate-resilient livelihoods (Manuamorn 2005; Linnerooth-Bayer and Mechler 2007). For example, the Nepalese Community-Based Adaptation to Weather-Related Disasters project referred to above aims to reduce overall vulnerability to natural disasters by facilitating the establishment of community-based micro-insurance schemes in the livestock and cash-crop sectors, and establishing communication between the National Meteorological Service of Nepal and the Community Based Disaster Preparedness Units (ACCA, 2008). More generally, preventive instruments such as insurances are increasingly advocated by governments and development agencies as the solution to address market-based shocks. Amongst these, index based weather insurance are attracting growing attention (Belete 2007; Skees, 2008, Dinku et al. 2009).

Third, a number of projects that combine all three domains explicitly utilise rights-based approaches in relation to vulnerability reduction. For example, the Earthquake 
Reconstruction and Rehabilitation Authority Rural Landless project in Pakistan (ERRA, 2008), which is based on recognition of people's rights to land, involves compensating families made landless by the 2005 earthquake and supporting them to re-build their livelihoods. Similarly, the Indian National Rural Employment Guarantee Scheme (NREGS) is a rights-based framework, including rights to employment (NREGS-AP 2006). Such rights-based interventions could have potentially important impacts on the livelihoods of rural households. More empirical research is needed however to document and assess more rigorously these impacts and critically evaluate the role that a more general ASP approach would have on the vulnerability of the poor in developing countries.

Finally, the research shows that each country has its own unique set of experiences which define different foci of SP, DRR and CCA interventions from which good practice can be drawn. The ASP approach needs to build on the strengths and experiences that each country offers, whilst bearing in mind that different countries are indisputably at different stages in terms of abilities to integrate SP, DDR and CCA. There is considerable potential, therefore, to share these experiences across the region, and it is worth investigating further what opportunities exist for investing in regional networks and organisations, as well as for cross-institutional learning. Further research in this area should focus on how much lesson-learning goes on within and between countries on these topics, what donors and national-level institutions can do to facilitate this, how to address existing institutional barriers to integration, and how good practice can be translated into policy change within government.

\section{Conclusion}

This research has shown that social protection, disaster risk reduction and climate change adaptation approaches are being brought together in development policy and practice in numerous ways. Building on the principles of the Adaptive Social Protection approach, the research presented here has provided a number of lessons and insights 
for the promotion of climate and disaster resilient social protection programmes, including the need to tackle underlying vulnerability and the identification of a number of innovative multi-disciplinary approaches.

Project implementers and policy-makers should therefore consider the possibility of joining up SP, DRR and CCA approaches into an ASP framework when designing vulnerability-reducing development interventions in the agricultural sector. One way to achieve this is to build on existing projects and programmes. Specific instruments could be added that would complement the already-built protection or prevention-oriented SP interventions with promotive, or even transformative, interventions. In addition, potential exists for projects that already integrate SP and DRR components to explore ways to build in CCA elements, especially in the light of a likely increase in adaptation funding in the coming years. This would help with extending the time horizon over which interventions are taking place, thus helping to find longer-term solutions of the impacts for disasters, as well as assisting people prepare for the impacts of climate change. 


\section{References}

ACCA, (2008) Application of Community-Based Adaptation Measures to Weather Related Disasters, Advancing Capacity to Support Climate Change Adaptation UNITAR Training Unit http://www.acccaproject.org/accca/?q=node/1

Adger, W. N. (2007) Climate change impacts, adaptation and vulnerability: Working Group II contribution to the fourth assessment report of the Intergovernmental Panel on Climate Change, Cambridge, Published for the Intergovernmental Panel on Climate Change by Cambridge Univ. Press.

Adger, W. N., Huq, S., Brown, K., Conway, D. and Hulme, M. (2003) Adaptation to climate change in the developing world. Progress in Development Studies 3, 179-195.

Alderman, H. and Haque, T. (2006) 'Countercyclical safety nets for the poor and vulnerable', Food Policy 31.4: 372-83.

Anon, (2006) Social Mobilisation in the Rural Community Infrastructure Works Programme (RCIW) in Nepal, http://www.methodfinder.net/example75 1.html

Ardlington, C., Case, A., and Hosegood, V., (2007) Labour Supply Responses to Large Social Transfers: Longitudinal Evidence from South Africa, NBER Paper available at http://www.princeton.edu/rpds/papers/pdfs/Case Ardington Hosegood NBER w13442 oc t07.pdf

Arnall, A., Oswald, K., Davies, M., Mitchell, T. and Coirolo, C. (2010) Adaptive Social Protection: Mapping the Evidence and Policy Context in the Agriculture Sector in South Asia. IDS working paper no 345. Brighton Institute of Development Studies.

Awuor, C. (2009) 'Increasing Drought in Arid and Semi-Arid Kenya , Kenya', In Ensor J. and Berger R.(eds.) Understanding Climate Change Adaptation: Lessons from Community-Based Approaches, Practical Action Publishing.

Azuara, O., (2009) Does Poverty Alleviation Increase Migration? Evidence from Mexico University of Chicago, available at http://mpra.ub.unimuenchen.de/17599/1/MPRA paper 17599.pdf

Barrientos, A., Hulme, D. and Shepherd, A. (2005) 'Can Social Protection tackle chronic poverty?', The European Journal of Development Research 17(1), 8-23.

Barrientos, A. and Hulme, D. (2008) Social protection for the poor and poorest in developing countries: reflections on a quiet revolution. BWPI Working Paper 30, Manchester: Brooks World Poverty Institute, University of Manchester, $26 \mathrm{p}$.

Barrientos, A., and Niño-Zarazúa, M., (2010) Do Social Transfer Programmes have Long-term Effects on Poverty Reduction? Chronic Poverty Research Centre, available at http://www.chronicpoverty.org/uploads/publication files/PB\%2020.pdf

Bayer, J.L. (2008) 'International Social Protection for Climate-Related Disasters', paper prepared for The Irrational Economist Conference and Book Writing in honour of Howard Kunreuther, Vienna, International Institute for Applied Systems Analysis (IIASA)

BCAS, (2004) Improving Capacity of Vulnerable Households project, Bangladesh Center for Advanced Studies, Dhaka http://www.bcas.net/ProjectBrief/com_project/RVCC.htm Béné C. 2011. Social Protection and Climate Change, IDS Bulletin 42(6): 67-70

Belete, N. (2007) Innovating to Reduce Risk: The case of livestock insurance in Mongolia." World Bank Agricultural and Rural Development Notes Issue 27. 
Bockel, L., Thoreux, M., et al. (2009) Resilience of Rural Communities to Climatic Accidents: A Need to Scale Up Socio-Environmental Safety Nets (Madagascar, Haiti), Policy Brief, Rome: Food and Agriculture Organization

Brooks, S., Thompson, J., Odame, H., Kibaara, B., Nderitu, S., Karin, K. and Millstone, E. (2009) Environmental Change and Maize Innovation in Kenya: Exploring Pathways In and Out of Maize, Brighton: STEPS Centre, Institute of Development Studies

Brown, T., Gibson, S. and Ashley, S. (2009) Building Consensus for Social Protection: Insights from Ethiopia's Productive Safety Net Programme (PSNP), London: Department for International Development

CARE (2009) CARE tackles vulnerability to climate change, downloaded from http://www.careclimatechange.org/files/adaptation/Adaptation09.pdf

Chambers, R. (1989) 'Editorial Introduction: Vulnerability, Coping and Policy' IDS Bulletin 20(2): 1-7.

Christoplos, I., Anderson, S., Arnold, M., Galaz, V., Hedger, M., Klein, R.J., and Le Goulven, K. (2009) The Human Dimension of Climate Adaptation: The Importance of Local and Institutional Issues. Commission on Climate Change and Development: Sweden.

Cipryk, R. (2009) Impacts of Climate Change on Livelihoods: What are the Implications for Social Protection? CDG Working Paper, Brighton: Institute of Development Studies.

Cleaver, F. (2005) The inequality of social capital and the reproduction of chronic poverty. World Development 33(6), 893-906.

Conroy, K., Goodman, A. R. and Kenward, S. (2010) 'Lessons from the Chars Livelihoods Programme, Bangladesh (2004-2010)', Paper presented at CPRC International Conference, Ten Years of 'War Against Poverty, University of Manchester 6 8-10th September 2010 Conway, T., Moser, C.; Norton, A. and Farrington, J. (2002) 'Rights and Livelihoods Approaches: Exploring Policy Dimensions', Natural Resource Perspectives, London, Overseas Development Institute, $78 \mathrm{p}$.

Cook, S. and Kabeer, N. (2009) Socio-economic security over the life course: A global review of social protection. Prepared as the final report of a Social Protection Scoping Study funded by the Ford Foundation, Brighton: Institute of Development Studies, Center for Social Protection, $34 \mathrm{p}$.

Cook, S., Kabeer, N. and Suwannarat, G. 2003. Social Protection in Asia, New Delhi: Ford Foundation.

Creti, P. and Jaspars, S. (eds). (2006) Cash Transfer Programming in Emergencies: A Practical Guide, London: Oxfam. http://www.oxfam.org.uk/publications

Davies, M.; Leavy, J.; Mitchell, T. and Tanner, T. (2008a) Social Protection and Climate Change, Briefing Note for Expert Group to the Commission on Climate Change and Development, Ministry of Foreign Affairs, Sweden.

Davies, M., Guenther, B.; Leavy, J.; Mitchell, T. and Tanner, T (2008b) 'Adaptive Social Protection: Synergies for Poverty Reduction', IDS Bulletin 39(4): 105-11

Davies, M.; Guenther, B.; Leavy, J.; Mitchell, T. and Tanner, T. (2009) Climate Change Adaptation, Disaster Risk Reduction and Social Protection: Complementary Roles in Agriculture and Rural Growth? Working Paper 320, Brighton: Institute of Development Studies 
Dercon, S. (2005) Vulnerability: A Micro-perspective, QEH Working Papers, Oxford: Queen Elizabeth House.

Dercon, S. (2011) Social protection, efficiency, and growth, paper written for the Annual Bank Conferences on Development Economics May 30 - June 1, Paris.

Devereux, S., Marshall, J., MacAskill, J., and Pelham, L. (2005) Making cash count: lessons from cash transfer schemes in East and Southern Africa for supporting the most vulnerable children and households, HelpAge International, Institute of Development Studies, Save the Children, http://www.ipc-undp.org/publications/cct/africa/MakingCashCountfinal.pdf

Devereux, S. and Coll-Black, S. (2007) Review of Evidence and Evidence Gaps on the Effectiveness and Impacts of DFID-supported Pilot Social Transfer Schemes, DST Evaluation, Brighton: Institute of Development Studies

Devereux, S. and Sabates-Wheeler, R. (2004) Transformative social protection, IDS Working Paper 232, Brighton: Institute of Development Studies, $36 \mathrm{p}$.

Devereux, S., Mvula, P., Solomon, C., (2006) After the FACT: An Evaluation of Concern Worldwide's Food and Cash Transfers Project in Three Districts in Malawi, Institute of Development Studies, available at http://www.ids.ac.uk/index.cfm?objectid=4F5B3743OF89-5F9A-23853011F138A7F2

Devereux, S. and. White. P. (2010) 'Social Protection in Africa: Evidence, Politics, and Rights', Poverty and Public Policy 2(3) http://www.psocommons.org/ppp/vol2/iss3/art5/.

Dinku, T., Giannini, A., Hansen, J., Holthaus, E., Ines, A., Kaheil, Y., Karnauska, K., Lyon, B., Madajewicz, M., Mclaurin, M., Mullally, C., Norton, M., Osgood, D., Peterson, N., Robertson, A., Shirley, K., Small, C. and Vicarelli, M. (2009) Designing index-based weather insurance for farmers. International research Institute for Climate and Society, Earth Institute, Columbia University, $84 \mathrm{p}$.

Ellis, F., White, P., Lloyd-Sherlock, P., Chhotray, V. and Seeley, J. (2008) Social Protection research scoping study, Governance and Social Development Resource Center, Norwich, UK: Overseas Development Group, University of East Anglia , 45 p.

ERD (2010) Social protection for inclusive development, a new perspective in EU cooperation with Africa, European Development Report, Robert Schuman Centre for Advanced Studies, European University Institute, $154 \mathrm{p}$.

ERRA (2008) ERRA's Rural Landless Programme, Earthquake Reconstruction and Rehabilitation Authority, Pakistan, www.erra.pk/Reports/Social\%20protection/Landless/LandlessBrief.pdf

FAO, (2011) FAO's Global Information and Early Warning System, Food and Agriculture Organization http://www.fivims.org/index.php?option=com_content\&task=view\&id=33\&ltemid=40

Fiott, D., Ndaruzaniye, V., Volkmann, E., Lipper, L., Demeke, M., Capaldo, J., Kantu, P.Y.T., Iwinjak, F.P., Flavell, A., Quesada, P., Clover, J. and Vincent, K. (2010) Climate Change and Security in Africa, Vulnerability Report for Africa, Climate Change, Environment and Security (ACCES), UNFAO, UNEP, Global Water Institute, Madariaga and the International Organization for Migration, $65 \mathrm{p}$.

Godfrey Wood, R. (2011) 'Is there a role for cash transfers in climate change adaptation?' in Devereux, S. and McGregor, J.A. (eds.) Social protection for Social justice, International Conference Institute of Development Studies, Brighton 13-15 April. 
Gol (2006) Concept Note for the pilot project on Climate Change Adaptation for Sustainable Rural Development, Ministry of Environment and Forests, Government of India, available at http://www.gtz.de/de/dokumente/en-climate-results-asia.pdf

Guhan, S. (1994) 'Social security options for developing countries', International Labour Review 133(1): 35-53

Harvey, P., (2007) Cash-Based Responses in Emergencies, London: Overseas Development Institute, available at http://www.odi.org.uk/resources/download/229.pdf

Hashemi, S.M. and Umaira, W. (2011) New pathways for the poorest: the graduation model from BRAC. CSP Research Report 10, Brighton: Center for Social Protection, Institute for Development Studies, $20 \mathrm{p}$.

Hellmuth, M.E., Mason, S., Vaughan, C., van Aalst, M. and Choularton R. (eds.) (2011) A Better Climate for Disaster Risk Management. Climate and Society No. 3, New York: International Research Institute for Climate and Society (IRI).

Heltberg, R. (2007) 'Helping South Asia cope better with natural disasters: the role of social protection', Development Policy Review 25(6), 681-698.

Heltberg, R., Siegel, P.S. and Jorgensen, S.L. (2009) 'Addressing Human Vulnerability to Climate Change: Towards a "No-regrets" Approach', Global Environmental Change 19: 89-99. Hodson, R. (2009) Reflections on the CLP Approach to Reducing Extreme Poverty: The Story Continues, London: Department for International Development.

ILO, (2007) Child Labour and Conditional Cash Transfer Programmes in Latin America, International Labour Organization, available at http://white.oit.org.pe/ipec/documentos/child labour and conditional cahs transfers.pdf IPCC, (2007) Climate Change 2007: Impacts, Adaptation and Vulnerability. Contribution of Working Group II to the Fourth Assessment Parry, M.L., Canziani, O.F., Palutikof, J.P., van der Linden P.J. and C.E. Hanson (eds.) Report of the Intergovernmental Panel on Climate Change. Islam K.M and D. Sanderson (2009) Institutional mobilization, governance and accountability thematic study. Shouhardo programme CARE Bangladesh, $34 \mathrm{p}$.

Jones, L., Jaspars, S., Pavanello, S., Ludi, E., Slater, R., Arnall, A., Grist, N. and Mtisi, S. (2010) Responding to a changing climate: Exploring how disaster risk reduction, social protection and livelihoods approaches promote features of adaptive capacity. Working Paper 319. London Overseas Development Institute, $32 \mathrm{p}$.

Kabeer, N., 2004, Re-visioning "the social": towards citizen-centred social policy for the poor in poor countries IDS working paper 191, Institute of Development Studies, Brighton

Kabeer, N., Cook, S., Chopra, D. and Ainsworth, P. (2010) Social protection in Asia: research findings and policy lessons, Programme Synthesis Report, Brighton: Social Protection in Asia, Institute of Development Studies, $56 \mathrm{p}$.

Kelman I., Gaillard J.C. (2008) 'Placing climate change within disaster risk reduction', Disaster Advances 1(3): 3-5.

Kelman, I., Mercer, J., West, J.J. (2009) 'Integrating indigenous and scientific knowledge for community-based climate change adaptation', Participatory Learning and Action 60: 41-53.

Lavell, A. (2004) Local Level Risk Management: From Concept to Practice. CEPREDENAC-UNDP. Quito. 
Levine, S. Ludi, E., and Jones, L., (2011) Rethinking support for adaptive capacity to climate change - the role of development interventions. A report for the Africa Climate Change Resilience Alliance, London: Overseas Development Institute, 49 p.

Lewis J. 2007. Climate and disaster reduction. Tiempo Climate Newswatch, available at http:// www.tiempocyberclimate.org/newswatch/comment070217.htm

Linnerooth-Bayer, J., Mechler, R. (2007) 'Insurance for Assisting Adaptation to Climate Change in Developing Countries: A Proposed Strategy', in E. Gurenko (Ed.) Climate Policy, Special Issue on Insurance and Climate Change.

Manuamorn, O. (2005) Scaling-Up Micro Insurance: The Case of Weather Insurance for Smallholders in India, Washington DC: World Bank.

Marks, M. (2007) Economic Impact of Cattle Transfers during the CLP's Asset Transfer Programme, Dhaka: Chars Livelihood Programme.

Marsh, R. (2002) Working with Local Institutions to Support Sustainable Livelihoods, Rome: Sustainable Development Division, Food and Agriculture Organisation of the United Nations. Matin, I., Sulaiman, M. and Rabbani, M. (2008) Crafting a Graduation Pathway for the Ultra Poor: Lessons and Evidence from a BRAC Programme. Chronic Poverty Research Centre (CPRC) Working Paper No. 109.

Mearns, R., and Norton, A. (2010) 'Equity and vulnerability in a warming world: introduction and overview', in Mearns, R. and A. Norton (eds), Social Dimensions of Climate Change: Equity and Vulnerability in a Warming World. Washington, DC: The World Bank, pp1-44 MHA, 2007 Annual Report 2007-08 Ministry of Home Affairs, Government of India, 170p. http://www.mha.nic.in/pdfs/ar0708-Eng.pdf

Mitchell, T. and van Aalst, M. (2008) Convergence of Disaster Risk Reduction and Climate Change Adaptation: a Review, London: Department for International Development.

Mitchell, T., van Maarten, A. and Villanueva, P.S. (2010) Assessing progress on integrating disaster risk reduction and climate change adaptation in development process, SCR Discussion Paper No.2, Brighton: Institute of Development Studies, Strengthening Climate Resilience Programme, $28 \mathrm{p}$.

Narayan, A. and Zaman, H. (2008) Poverty Assessment for Bangladesh: Creating Opportunities and Bridging the East-West Divide, Washington DC: World Bank.

Neves, D., Samson, M., van Niekerk, I., Hlathshwayo, S., and du Toit, A., (2009) The Use and Effectiveness of Social Grants in South Africa, PLAAS and EPRI, executive summary available at

http://www.wahenga.net/sites/default/files/library/The\%20use\%20and\%20effectiveness E xec\%20Sum.pdf

NREGS-AP (2006) National Rural Employment Guarantee Scheme, Department of Rural Development, Government of Andhra Pradesh, http://nrega.ap.gov.in/Nregs/Home eng.jsp

O'Brien G, O'Keefe P, Rose J, Wisner B. (2006) 'Climate change and disaster management', Disasters 30(1): 64-80.

O'Brien, K., Sygna, L., Leichenko, R., Adger, N., Barnett, J., Mitchell, T., Schipper, L., Tanner, T., Vogel, C. and Mortreux, C. (2008) Disaster Risk Reduction, Climate Change Adaptation and Human Security, A Commissioned Report for the Norwegian Ministry of Foreign Affairs, Oslo: Global Environmental Change and Human Security 
Oxfam G.B., and Concern Worldwide, (2007) Cash transfers as a response to disaster: responses in Western Zambia, available at http://www.oxfam.org.uk/resources/countries/downloads/zambia cash transfers 200805. pdf

Practical Action, (2009) Good practice for Resilience action, Mainstreaming Livelihood-Centred Approaches to Disaster Management project, Dhaka: Practical Action Bangladesh Office http://practicalaction.org/docs/ia1/good-practices-community-resiliance-052009.pdf

Schipper, L. (2009) 'Meeting at the Crossroads? Exploring the Linkages between Climate Change Adaptation and Disaster Risk Reduction', Climate and Development 1: 16-30.

Scoones, I. (1998) Sustainable Rural Livelihoods: A Framework for Analysis, Working Paper 72, Brighton: Institute of Development Studies.

Sen, B. (2003) 'Drivers of Escape and Descent: Changing Household Fortunes in Rural Bangladesh', World Development 31(3): 513-534

Shea, E. 2003. Living with a Climate in Transition: Pacific Communities Plan for Today and Tomorrow, East-West Center: Honolulu.

Shepherd, A. (2008) Think Piece for EADI/DSA/IDS/ActionAid High Level Policy Forum on the $M D G s$, London: Overseas Development Institute.

Skees, J. (2008) Challenges for use of index-based weather insurance in lower income countries. Lexington, KY, USA: GlobalAgRisk, $24 \mathrm{p}$.

Soares, F.V., Ribas, R.P., Hirata, G.I., (2008) Achievements and Shortfalls of Conditional Cash Transfers: Impact Evaluation of Paraguay's Tekoparã Programme, International Poverty Centre, available at http://www.ipc-undp.org/pub/IPCEvaluationNote3.pdf

Sperling, F., Szekely, F. (2005) Disaster Risk Management in a Changing Climate, Discussion paper prepared for the World Conference on Disaster Reduction on behalf of the Vulnerability and Adaptation Resource Group (VARG), Washington, DC: World Bank.

Stern, N. (2006) The Economics of Climate Change: The Stern Review, Cambridge: Cambridge University Press.

Stern, N. (2009) Blueprint for a Safer Planet: How to Manage Climate Change and Create a New Era of Progress and Prosperity, The Bodley Head Ltd.

Stirbu, M. (2010) Climate change, children and youth in Cambodia: Successes, challenges and policy implications, Children in a Changing Climate. UNICEF Policy Brief, http://www.childreninachangingclimate.org/database/ids/Publications/IDSPolicyReport WE B PDF.pdf

Tearfund (2008) Linking Climate Change Adaptation and Disaster Risk Reduction, London: Tearfund.

Tanner, T.M., Hassan, A., Islam, K.M.N., Conway, D., Mechler, R., Ahmed, R.U. and Alam, M. (2007) ORCHID: Piloting Climate Risk Screening in DFID Bangladesh, Research Report, Brighton: Institute of Development Studies.

Thomalla F., Downing T., Spanger-Springfield E., Han G., and Rockstrom J., (2006) 'Reducing hazard vulnerability: towards a common approach between disaster risk reduction and climate adaptation', Disasters 30(1): 39-48.

UNDP (2008) Human Development Report 2007/2008 - Fighting Climate Change: Human Solidarity in a Divided World, New York: United Nations Development Programme. 
UNISDR (2008). Briefing Note: Climate Change and Disaster Risk Reduction, Geneva: United Nations International Strategy for Disaster Reduction.

Vakis, R. (2006) Complementing Natural Disasters Management: The Role of Social Protection, Washington DC: World Bank

V\&A (2009). Vulnerability and adaptation experiences from Rajastahn and Andhra Pradesh: community based institutions Swiss Agency for Development V\&A Programme, India

Wisner, B. (2009) 'Vulnerability', in Kitchin, R. and Thrift, N., (eds.) International Encyclopedia of Human Geography. Oxford: Elsevier.

World Bank (2011) Making Social Protection work for pro-poor disaster risk reduction and climate change adaptation, International workshop organized by the World Bank, the Institute of Development Studies, the UK Department for International Development, and the United Nations Economic Commission for Africa, Addis Ababa 13-17 March 2011, draft report.

World Bank (2011) Building resilience and opportunities, World Bank's Social Protection and Labour Strategy 2012-2022, Washington DC: World Bank.

WRI (2007) Indian Pilot Project on Climate Change Adaptation for Sustainable Rural Development http://projects.wri.org/adaptation-database/india-pilot-project-climatechange-adaptation-sustainable-rural-development 
Figure 1: Conceptual representation of adaptive social protection

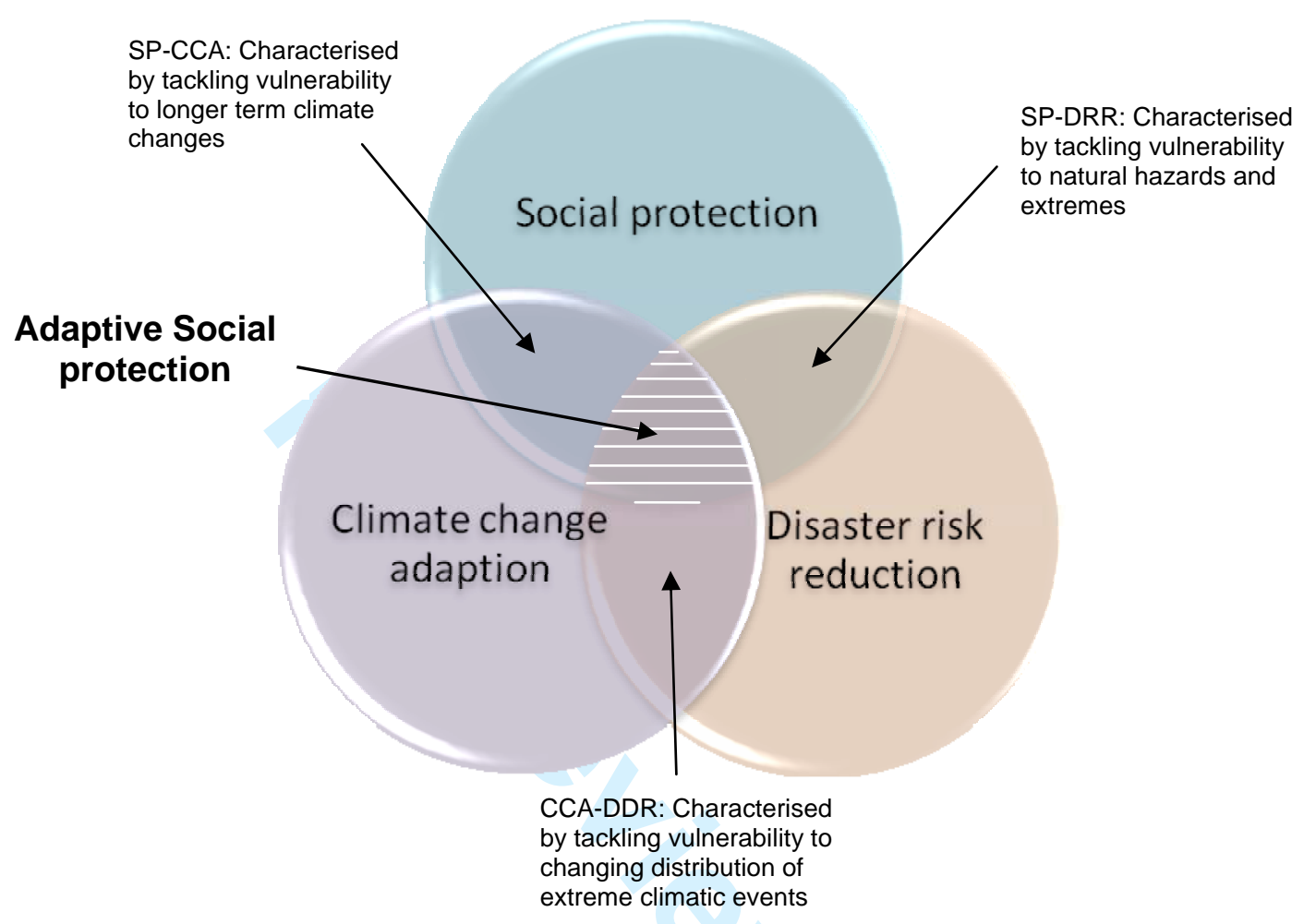

Adapted from Davies et al. (2009) 
Fig.2. Types of interventions as a function of the degree of integration of SP with DRR and CCA (toward ASP).

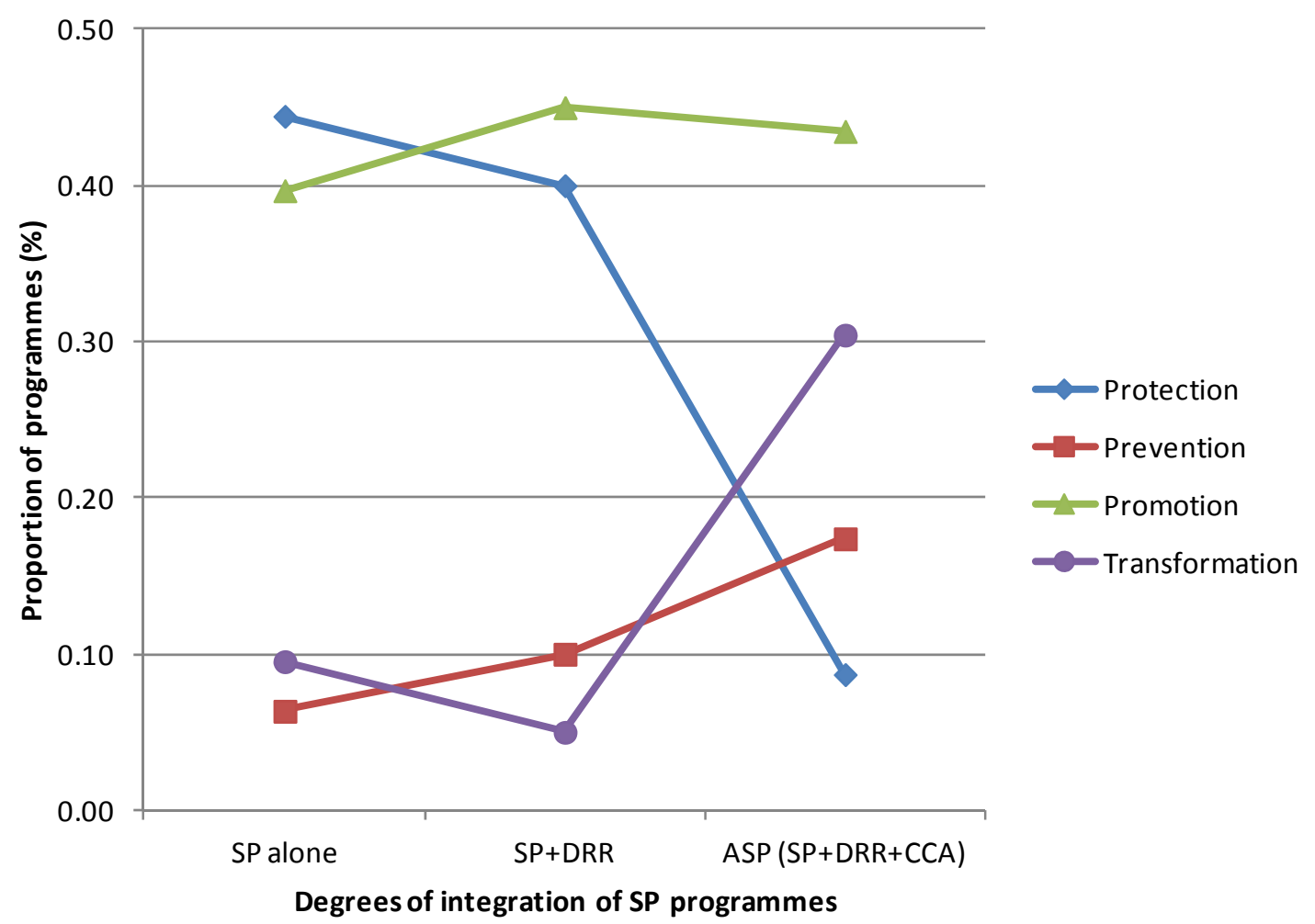


Table 1. Promoting Climate change adaptation and disaster risks reduction through adaptive social protection

\begin{tabular}{|c|c|c|c|}
\hline Time frame & SP category & SP instruments & CCA and DRR benefits \\
\hline $\begin{array}{c}\text { Short-term } \\
\square\end{array}$ & $\begin{array}{l}\text { Protective (coping } \\
\text { strategies) }\end{array}$ & $\begin{array}{l}\text { - Social service protection } \\
\text { - Basic social transfers } \\
\text { (food/cash) } \\
\text { - Pension schemes } \\
\text { - Public works programmes }\end{array}$ & $\begin{array}{l}\text { - Protection of those most } \\
\text { vulnerable to climate risks, } \\
\text { with low levels of adaptive } \\
\text { capacity }\end{array}$ \\
\hline & $\begin{array}{l}\text { Preventive (coping } \\
\text { strategies) }\end{array}$ & $\begin{array}{l}\text { - Social transfers } \\
\text { - Livelihood diversification } \\
\text { - Weather-indexed crop } \\
\text { insurance }\end{array}$ & $\begin{array}{l}\text { - Prevents damaging coping } \\
\text { strategies as a result of risks } \\
\text { to weather-dependent } \\
\text { livelihoods }\end{array}$ \\
\hline 7 & $\begin{array}{l}\text { Promotive (building } \\
\text { adaptive capacity) }\end{array}$ & $\begin{array}{l}\text { - Social transfers } \\
\text { - Access to credit } \\
\text { - Asset transfers/protection } \\
\text { - Starter packs } \\
\text { (drought/flood resistant) } \\
\text { - Access to common } \\
\text { property resources } \\
\text { - Public works programmes }\end{array}$ & $\begin{array}{l}\text { - Promotes resilience through } \\
\text { livelihood diversification and } \\
\text { security to withstand climate } \\
\text { related shocks } \\
\text { - Promotes opportunities } \\
\text { arising from climate change }\end{array}$ \\
\hline Long-term & $\begin{array}{l}\text { Transformative } \\
\text { (building adaptive } \\
\text { capacity) }\end{array}$ & $\begin{array}{l}\text { - Promotion of minority } \\
\text { rights } \\
\text { - Anti-discrimination } \\
\text { campaigns } \\
\text { - Social funds }\end{array}$ & $\begin{array}{l}\text { - Transforms social relations } \\
\text { to combat discrimination } \\
\text { underlying social and } \\
\text { political vulnerability }\end{array}$ \\
\hline
\end{tabular}

Adapted from Davies et al. (2009) 
Table 2. Degree of integration of approaches from the perspective of individual policy domain

\begin{tabular}{cccc}
\hline Domain & $\begin{array}{c}\text { No integration with } \\
\text { other domains }\end{array}$ & $\begin{array}{c}\text { Integration with one } \\
\text { other domain }\end{array}$ & $\begin{array}{c}\text { ASP = Integration with } \\
\text { two other domains }\end{array}$ \\
\hline SP & $48(49 \%)$ & $31(32 \%)$ & $18(19 \%)$ \\
DRR & $4(6 \%)$ & $50(69 \%)$ & $18(25 \%)$ \\
CCA & $1(2 \%)$ & $25(57 \%)$ & $18(41 \%)$ \\
\hline
\end{tabular}

Data source: Arnall et al. (2010) 
Table 3. Degree of integration of SP, DRR and CCA approaches in vulnerability-reducing projects in South Asia

\begin{tabular}{cccccccc}
\hline & $\begin{array}{c}\text { SP (no } \\
\text { integration) }\end{array}$ & $\begin{array}{l}\text { DRR (no } \\
\text { integration) }\end{array}$ & $\begin{array}{c}\text { CCA (no } \\
\text { integration) }\end{array}$ & $\begin{array}{c}\text { SP-DDR } \\
\text { integration }\end{array}$ & $\begin{array}{c}\text { SP-CCA } \\
\text { integration }\end{array}$ & $\begin{array}{c}\text { DRR-CCA } \\
\text { integration }\end{array}$ & $\begin{array}{c}\text { ASP = full } \\
\text { integration }\end{array}$ \\
\hline Regional & 0 & 0 & 0 & $3(75 \%)$ & 0 & $1(25 \%)$ & 0 \\
Afghanistan & $8(68 \%)$ & 0 & 0 & $2(17 \%)$ & $1(8 \%)$ & 0 & $1(8 \%)$ \\
Bangladesh & $13(35 \%)$ & 0 & 0 & $7(19 \%)$ & 0 & $9(24 \%)$ & $8(22 \%)$ \\
India & $14(36 \%)$ & $2(5 \%)$ & 0 & $8(21 \%)$ & 0 & $7(18 \%)$ & $8(21 \%)$ \\
Nepal & $6(38 \%)$ & $2(13 \%)$ & $1(6 \%)$ & $2(13 \%)$ & $2(13 \%)$ & $2(13 \%)$ & $1(6 \%)$ \\
Pakistan & $7(44 \%)$ & 0 & 0 & $6(38 \%)$ & 0 & $3(19 \%)$ & 0 \\
Total & 48 & 4 & 1 & 28 & 3 & 22 & 18 \\
\hline
\end{tabular}

Data source: Arnall et al. (2010) 
Pilot Project on Climate

Change Adaptation for

Sustainable Rural Development (Gol 2006; V\&A 2009)

Shouhardo project (Islam and Sanderson 2009; CARE 2009)
Summary of objective and/or activities

The Chars Livelihood Programme (CLP) (2004-2010) aimed to increase the income and wealth of extreme poor households in north-west Bangladesh through a number of mutually re-enforcing activities: first through an asset transfer component, i.e. a one-off productive asset grant made available to participant households. Supporting this transfer were interventions targeted at the household level: basic infrastructure improvements to mitigate against environmental vulnerability and improve household sanitation facilities and access to clean drinking water; homestead garden inputs to increase household food security; social development education to raise social and human capital, and improve social cohesion; cash stipends to buoy consumption and support the asset transfer; and enterprise activities to boost household level income earning opportunities. In addition, large pilots were undertaken in the health, nutrition, education and community based savings areas. Significant employment opportunities were also provided during relatively food insecure seasons for participant households and the wider community through various public cash-for-work schemes.

The overall goal of the Vulnerability Assessment and Enhancing Capacities to Climate Change in Arid regions in India (V\&A) programme (2005-2009) was to secure the livelihood of rural poor and vulnerable communities by promoting adaptation measures that enhance their capacities to better cope with adverse impacts of climate change and by improving their disaster preparedness. A range of activities some of which built on and aligned to traditional local adoptions practices were tested in the particularly climate sensible sectors of water agriculture, rural energy and livestock. Water users committees were formed or revived as part of interventions to rehabilitate tanks, upgrade a traditional harren system and establish a water bank for improving irrigation. Pasture management committees were established in order to ensure sustainable management of common land. Smart farmers clubs were formed in all programme villages as platforms for knowledge exchange and to facilitate the adoption of new farming practices.

The main goal of the Shouhardo programme (2004-2010) was to sustainably reduce household chronic and transient food insecurity in Bangladesh through the establishment of partnership with vulnerable communities, local civil society and government authorities with the objective to develop targeted Community-Based Adaptation (CBA) programmes and integrate climate change adaptation in the design of development initiatives. Four strategic strains of activities were conducted in parallel, that aimed at: (i) improve availability/economic access to food through strengthening livelihoods, entitlements and enhancing accountability of service providers; (ii) sustainably improve the health and nutrition of households participating in the project; (iii) enhance empowerment of women and girls from the targeted vulnerable households, and (iv) strengthen targeted communities and institutions capacities to prepare for mitigation and response to natural disaster. 
Appendix 1. List of 124 programmes included in the analysis and their degrees of integration between climate change adaption (CCA), disaster risk reduction (DRR), and social protection (SP).

\begin{tabular}{|c|c|c|c|}
\hline Regional & CCA & DRR & SP \\
\hline Regional Support to Alleviate the Impact of Soaring Food Prices on the Most Affected Vulnerable Farming Populations of Asia (FAO) & & $\mathrm{x}$ & $\mathrm{x}$ \\
\hline Special Programme for Food Security (SPFS) (FAO) & & $\mathrm{x}$ & $\mathrm{x}$ \\
\hline Food Crisis Response Programme (Word Bank) & & $\mathrm{x}$ & $\mathrm{x}$ \\
\hline From Risk to Resilience (ISET - Nepal/India/Pakistan) & $\mathrm{x}$ & $\mathrm{x}$ & \\
\hline \multicolumn{4}{|l|}{ Bangladesh } \\
\hline VGD (includes Income Generation for VGD (IGVGD), Food Security for VGD (FSVGD), Union Parishad VGD, UPVGD) (BRAC) & & & $\mathrm{x}$ \\
\hline Rural Infrastructure Maintenance Programme (RIM) (GoB/EC/CIDA) & & $\mathrm{x}$ & $\mathrm{x}$ \\
\hline Test Relief (TF) (GoB/Development Partners) & & $\mathrm{x}$ & $\mathrm{x}$ \\
\hline Gratuitous Relief (GT) (GoB/Development Partners) & & $\mathrm{x}$ & $\mathrm{x}$ \\
\hline Enhancing Resilience Activity (ER) (incl. Food For Training (FFT) and Food for Assets (FFA)) (GoB/WFP) & & $\mathrm{x}$ & $\mathrm{x}$ \\
\hline Social Investment Programme Project (SIPP) (World Bank/GoB) & $\mathrm{x}$ & $\mathrm{x}$ & $\mathrm{x}$ \\
\hline Reducing Vulnerability to Climate Change (RVCC) (CARE) & $\mathrm{x}$ & $\mathrm{x}$ & \\
\hline Flood Risk Reduction Activities in Sunamganj (FRRAS) (CARE/SDC) & & $\mathrm{x}$ & $\mathrm{x}$ \\
\hline Mainstreaming Livelihood-Centred Approaches to Disaster Management (Practical Action) & $\mathrm{x}$ & $\mathrm{x}$ & $\mathrm{x}$ \\
\hline CFRP-TUP (BRAC) & & & $x$ \\
\hline Enhancing Adaptive Capacity to Prolonged Flood and Water-Logging in a South Central Floodplain (SSN) & $x$ & $x$ & \\
\hline Rural Infrastructure Development and Job Creation Measures (RIDJCM) (Caritas Bangladesh) & & & $\mathrm{x}$ \\
\hline Flood-Resistant Housing through Micro-Loans (Grameen) & $\mathrm{x}$ & $\mathrm{x}$ & $\mathrm{x}$ \\
\hline Employment Creation through Sericulture (Caritas Bangladesh) & & & $\mathrm{x}$ \\
\hline
\end{tabular}


Disaster Management Programmes (includes several initiatives) (Caritas Bangladesh) Community Based Early Warning System (Bangladesh Disaster Preparedness Centre, BDPC) Governance and Disaster Risk Reduction Programme (BDPC)

Capacity Building of Village Disaster Management Committees (BDPC)

Community Based Disaster Preparedness Programme (CBDPP) (Bangladesh Red Crescent Society) Integrated Planning for Sustainable Water Management (IPSWAM) (GoB)

Livelihood Adaptation to Climate Change (LACC, phases 1, 2, 3) (Dept.Agri. Extension, GoB/FAO)

Comprehensive Disaster Management Programme, CDMP (MoFDM/UNDP/DFID)

Fund for Housing for the Distressed (Grihayan Tahabil)

Allowances to the Widowed, Deserted and Destitute Women (GoB)

Adaptive Agriculture Programme (CNRS)

Shiree (Challenge Fund for Economic Empowerment of the Poorest) (DFID/GoB)

Chars Livelihoods Programme (DFID)

Cash for Education (GoB/USAID)

Female Secondary School Assistance Programme (FSSAP) (GoB)

Employment Guarantee Scheme (GoB)

OAAS / APWDW

Primary Education Stipend Project, PESP (GoB)

\section{India}

NREGA (set to replace the FFW projects listed below)

Jawahar Rozgar Yojana (JRY) and Sampoorna Gramin Rozgar Yojana (National FFW projects)

Mid-Day Meal Programme (MDM) (Gol)

ICDS (Improving Nutritional Status of Vulnerable Children and Women) (Gol/WFP)

Madhya Pradesh Rural Livelihoods Programme (MPRLP, DFID)

Andhra Pradesh Rural Livelihoods Programme (APRLP, DFID)

West Bengal Rural Livelihoods Programme (WBRLP, DFID)

Inclusive Risk Transfer Initiative, All India Disaster Mitigation Institute (AIDMI)

Afat Vimo (AIDMI) 
District Poverty Initiative Project (DPIP) (World Bank/Gol)

$\begin{array}{lll} & x & x \\ x & x & \\ & x & x \\ & & x \\ & & x \\ x & x & \\ & x & x \\ & x & x \\ & & x \\ x & x & \\ x & x & \\ x & x & x \\ x & x & x \\ x & x & x \\ & x & x \\ x & x & \\ & & x \\ & x & \\ x & x & x \\ & x & \\ & & x \\ x & x & \\ & x & \\ & & x \\ & x & x \\ & & x \\ & & \\ & & \\ & & \\ & & \\ & x\end{array}$

Drought Prone Areas Programme (DPAP) (Gol)

Calamity Relief Fund (Gol)

National Calamity Contingency Fund (Gol)

Swarnajayanti Gram Swarozgar Yojana (SGSY) (Dept Rural Development)

Rural Infrastructure Development Fund (RIDF) (NABARD)

Desert Development Programme (DPP) (Gol)

Integrated Watershed Development Programme (Dept. of Agriculture)

National Watershed Development Programme for Rainfed Areas (NWDPRA)

Antyodaya Anna Lojana

Integrated Wasteland Development Programme (IWDP) (Gol)

Watersheds Organizations Trust (WOTR) (NABARD)

Bharat Agro-Industries Foundation (BAIF)

Sanjojana (Agragame)

Western Orissa Rural Livelihoods Programme (WORLP, DFID)

VIKALP (Sustainable Livelihoods options in Disaster Prone Villages in Surendranagar District) (CEE/ADB)

Watershed Management Programme (SDC)

Development of Women and Children in Rural Areas (DWACRA) (SHGs)

CBDP, Caritas India

Community-based drought (CARE)

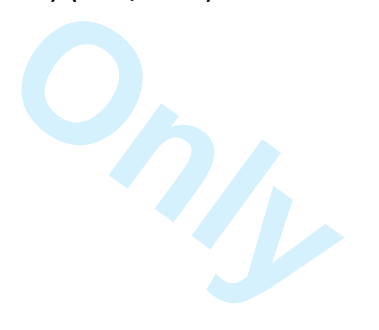

CASHE (Care India)

Climate Resilient Development and Adaptation (UNDP)

Disaster Management and Response Programmes (CARE)

Employment Guarantee Scheme, Maharashtra

National Agriculture Insurance Scheme (NAIS)

Pilot Project on Climate Change Adaptation for Sustainable Rural Development (Gol) 
NOAPS (Gol)

Rural Access Programme (Word Bank/DFID)

Rural Community Infrastructure Works (DFID)

Poverty Alleviation Fund (Word Bank)

Strengthening Capacities for Disaster Prevention and Preparedness and Climate Risk Management in the Agricultural Sector (FAO)

Food Assistance For Populations Affected by Conflict \& High Food Prices (WFP)

Enhanced CSOs' Capacity for Right-Based Livelihoods Program (CARE)

Agriculture Innovations for Livelihood Security (LiBird)

Adaptation to Climate Change (LiBird)

DIPECHO (ActionAid/CARE/Practical Action)

Churia Livelihood Improvement Programme (CARE)

Capacity Development of the Poor for Reducing Disaster Risk (NCDM)

Application of Community Based Adaptation Measures to Weather Related Disasters (Himalayan Climate Centre)

Support to Adaptation and Risk Management (ICIMOD)

Kuna Scheme

Livelihoods Forestry Project (DFID)

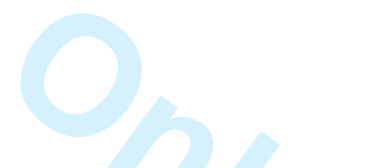

\section{Pakistan}

Pakistan Bait-ul-Maal (PBM) (GoP)

Zakat (GoP)

Benizar Income Support Programme (GoP)

Child Support Programme (Pilot)

National Rural Support Programme (GoP)

Balochistan Rural Development and Drought Mitigation Project (ADB)

Poverty Alleviation Fund (Word Bank)

Earthquake Livelihood Support Cash Grants (Word Bank) 
EMOP - Food Assistance for the Vulnerable Populations Affected by the High Food Prices in Pakistan (WFP) PRRO - Assistance to Food Insecure Households in Balochistan and the Federally Administered Tribal Areas (WFP) Thardeep Rural Development Programme, part of Rural Support Programmes Network (DFID) Cash Transfers programme (Save the Children)

Livelihoods Recovery programme (Oxfam) ERRA Landless Programme (UNHabitat)

Project to Assist ERRA and its Partners in Restoring Livelihoods in the Earthquake Affected Areas (FAO) Food Security Information and Early Warning System (FSIEWS) (FAO)

\section{Afghanistan}

Food-For-Work, PRRO (WFP)

$$
\text { ) (FAO) }
$$

Expanding Microfinance Outreach and Improving Sustainability project (Word Bank)

Emergency Rural Access Project (NERAP) (GoA/Word Bank)

CRS Seed Voucher Programmes

Integrated Shelter (CARE)

National Solidarity Programme (GoA, DFID)

Saleh Project (DFID)

Emergency Employment Programme for Demobilisation, Disarmament, and Reitegration and rural Livelihood Support (Word Bank)

National Emergency Employment Program (Word Bank)

Food security and Livelihood promotion programmes (several initiatives) (FAO)

Emergency Livestock and Horticulture project (Word Bank/GoA)

Greening of Afghanistan Initiative (GAIN) (WFP)

\begin{tabular}{|c|c|c|}
\hline & $x$ & $x$ \\
\hline & $x$ & $x$ \\
\hline \multirow[t]{4}{*}{$x$} & $x$ & \\
\hline & & $x$ \\
\hline & & $x$ \\
\hline & $x$ & $x$ \\
\hline$X$ & $x$ & $x$ \\
\hline \multirow[t]{7}{*}{$X$} & $x$ & \\
\hline & & $x$ \\
\hline & & $x$ \\
\hline & & $x$ \\
\hline & & $x$ \\
\hline & $x$ & $x$ \\
\hline & & $x$ \\
\hline \multirow[t]{5}{*}{$x$} & & $x$ \\
\hline & & $x$ \\
\hline & & $X$ \\
\hline & $x$ & $x$ \\
\hline & & \\
\hline$X$ & $x$ & $X$ \\
\hline
\end{tabular}

Note: GoA: Government of Afghanistan: GoP: Government of Pakistan: Gol : Government of India; GoN: Government of Nepal; GoB: Government of Bangladesh. 